\title{
Association of blaCTX-M-15 and qnr genes in multidrug-resistant Salmonella Typhimurium and Shigella spp from India
}

\author{
Dhiviya Prabaa Muthuirulandi Sethuvel ${ }^{1}$, Shalini Anandan ${ }^{1}$, Naveen Kumar Devanga Ragupathi ${ }^{1}$, Balaji \\ Veeraraghavan $^{1}$, Ohri Vinod ${ }^{2}$, Kamini Walia ${ }^{2}$ \\ ${ }^{1}$ Department of Microbiology, Christian Medical College, Vellore, India \\ ${ }^{2}$ Indian Council of Medical Research, Ansari Nagar, New Delhi, India
}

Key words: non-typhoidal Salmonella; Shigella; bla $a_{\mathrm{CTX}-\mathrm{M}-15}$; qnr; AmpC; ESBL.

J Infect Dev Ctries 2015; 9(11):1294-1297. doi:10.3855/jidc.6965

(Received 04 April 2015 - Accepted 24 May 2015)

Copyright (C) 2015 Muthuirulandi Sethuvel et al. This is an open-access article distributed under the Creative Commons Attribution License, which permits unrestricted use, distribution, and reproduction in any medium, provided the original work is properly cited.

Dear Editor,

Acute infectious diarrhoea continues to be a significant cause of morbidity and mortality in children in low income countries. Among bacterial isolates, Shigella spp and Salmonella spp are known to contribute to the high burden of this illness in children. Recent literature survey reveals a sharp declining of prevalence of $S$. Typhi, while non-typhoidal Salmonella (NTS) and Shigella flexneri are increasing [1]. Among the Shigella isolates, $>90 \%$ are resistant to ampicillin and sulfonamides [2], $4 \%-10 \%$ of isolates are resistant to at least one of the thirdgeneration cephalosporins (ceftriaxone/cefotaxime) $[3,2]$, and $7 \%-33 \%$ to fluoroquinolones [2]. Whereas in NTS, $86 \%$ are resistant to ampicillin, $33 \%-48 \%$ to sulfonamides $[4,5], 34 \%$ to third-generation cephalosporins [3], and 24\%-35\% to fluoroquinolones [4,5]. Monitoring of cephalosporins and fluoroquinolones resistance is particularly important because these antibiotics are among the few therapeutic options commonly used for moderate to severe Salmonella and Shigella infections.

The objective of this study was to determine the co-existence of $q n r$ and extended-spectrum $\beta$ lactamase (ESBL) genes in clinical isolates of multidrug-resistant (MDR) Shigella spp and Salmonella spp. (defined here as isolates resistant to $\geq$ 3 drugs)

\section{The study}

Faecal Salmonella spp and Shigella spp culture isolates obtained from the Christian Medical College (CMC), Vellore, India, during the year 2014 were included in this study. Totally, 3,461 faeces specimens were processed between January and December 2014, among these $18.43 \%(n=638)$ faecal pathogens were identified. Isolation and identification of the organism was carried out using standard protocol. Isolates were serotyped by using commercial antisera (Denka Seiken, Tokyo, Japan). Of these, $25.7 \%(\mathrm{n}=164)$ were Salmonella spp. (including four S. Typhi) and 25.5\% $(\mathrm{n}=163)$ were Shigella spp. This included S. flexneri $(\mathrm{n}=111), S$. dysenteriae $(\mathrm{n}=5), S$. sonnei $(\mathrm{n}=33), S$. boydii $(\mathrm{n}=2)$ and non-agglutinable Shigellae $(\mathrm{n}=12)$. Of these, $2.5 \%(\mathrm{n}=4)$ Salmonella spp. and $3.6 \%$ of Shigella spp. $(\mathrm{n}=6)$ which included $S$. flexneri $(\mathrm{n}=5)$ and one $S$. sonnei, were MDR by disk diffusion method according to interpretative breakpoints recommended by the Clinical Laboratory Standards Institute (CLSI) guidelines 2014 [6]. The phenotypic antibiotic susceptibility profiles of all $10 \mathrm{MDR}$ isolates are given in Table 1. Among the 10 MDR isolates, all were resistant to all antibiotics tested except one Shigella isolate which was susceptible to norfloxacin.

Increasing prevalence and various types of ESBLs and AmpCs are being reported in Enterobacteriaceae [7]. Nonetheless, in India such reports for Shigella spp and non-typhoidal Salmonellae are not often seen (Table 2). The most frequently encountered ESBLs belong to the $b l a_{\mathrm{CTX}-\mathrm{M}}, b l a_{\mathrm{SHV}}$, and $b l a_{\mathrm{TEM}}$ families.

In this study, the MDR isolates were found to harbour the genes bla $a_{\mathrm{OXA}}, b l a_{\mathrm{TEM}}$, dhfrla, sul2, qnrA, $q n r \mathrm{~B}, q n r \mathrm{~S}, \mathrm{AmpC}$ and $b a_{\mathrm{CTX}-\mathrm{M}}$ as shown in Table 1. Of these, two Shigella isolates were positive for $b l a_{\text {OXA }}$ and one for $b l a_{\mathrm{TEM}}$. 
$\underline{\text { Table 1. Multi-drug resistant Salmonella spp and Shigella spp with phenotypic and molecular profiles }}$

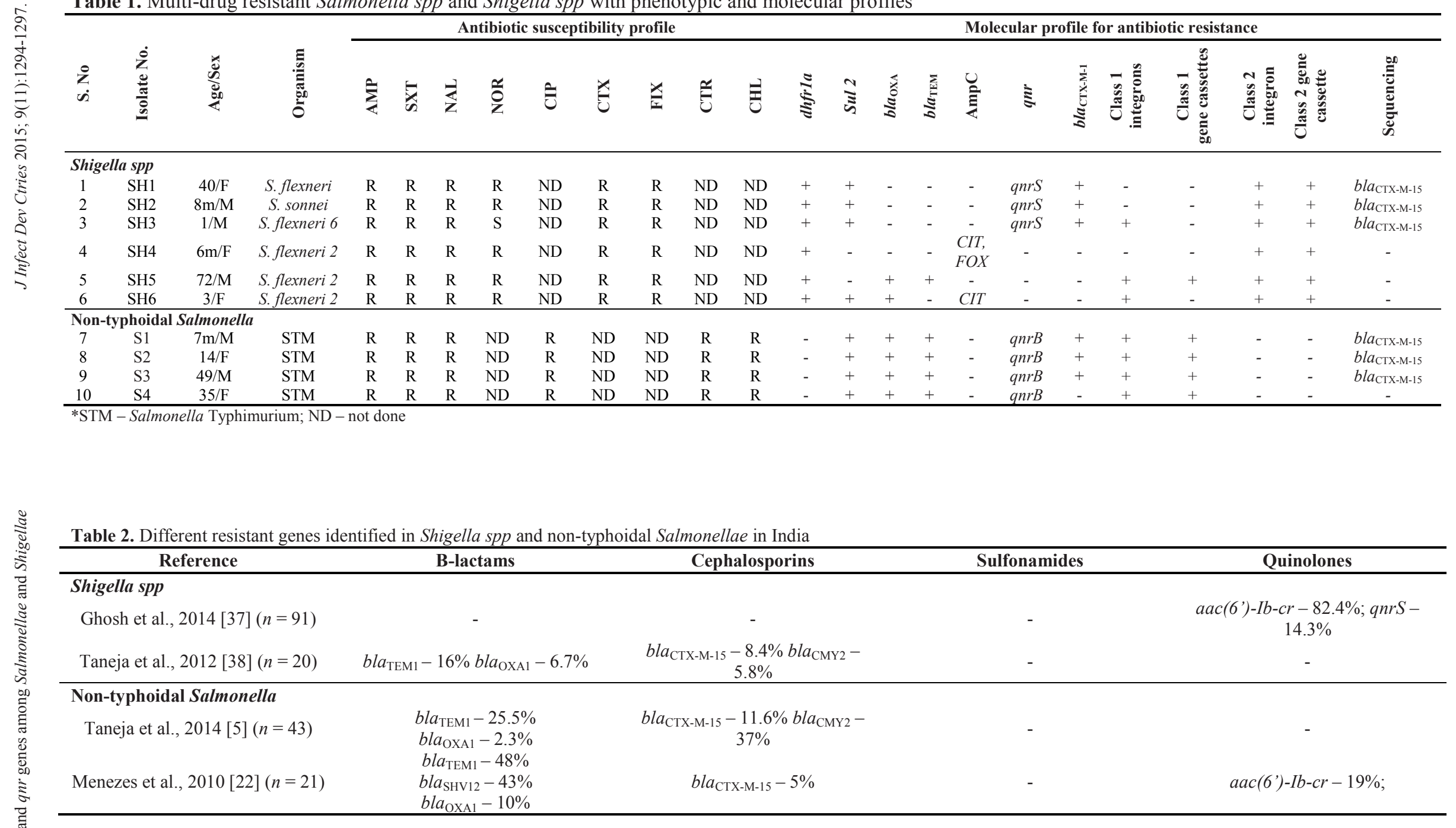


All six Shigella isolates were positive for dhfrla and four for sul2 thereby conferring resistance for trimethoprim-sulfamethoxazole, while three Shigella isolates were found to possess $q n r \mathrm{~S}$ genes coding for quinolone resistance. Meanwhile, the four MDR STMs were all found to be positive for $b l a_{\mathrm{OXA}}, b l a_{\mathrm{TEM}}$, Sul2 and $q n r \mathrm{~B}$. Further, all six Shigella isolates harboured class 2 integrons, three of which had both class 1 and 2 integrons. All four STM were found to harbour class 1 integrons. The resistant determinants of trimethoprimsulfamethoxazole were known to be associated with class 1 and class 2 integrons [8].

Liu et al. [9] reported that $91.7 \%$ of the plasmidmediated quinolone resistance (PMQR) positive Shigella isolates co-harboured bla $a_{\mathrm{OXA}} \beta$-lactamase gene and class 2 integrons. In contrast, none of the PMQR positive Shigella isolates co-harboured bla $a_{\text {OXA }}$ gene but all were positive for class 2 integrons in the present study. In addition, $100 \%$ of the PMQR positive Shigella isolates were also positive for $b l a_{\text {СТХ-M-1 }}$ gene, which again differ with the $58.3 \%$ reported by Liu et al. [9]. Interestingly, in this study, $100 \%$ of the PMQR positive STM co-harboured both $b l a_{\mathrm{OXA}}$ and class 1 integrons.

bla $a_{\mathrm{CTX}-\mathrm{M}-14}$ and $b l a_{\text {СTX-M-15 }}$ were identified to be the most common types of cefotaximases among NTS and Shigella spp [10]. Recently, Menezes et al. [11] submitted the first report of bla $a_{\mathrm{CTX}-\mathrm{M}-15}$ producing STM in India, which was followed by a report in other serovars by Taneja et al. [5].

Plasmid-mediated AmpC $\beta$-lactamases are another class of enzymes responsible for resistance to cephalosporins. The organisms over expressing ESBL and AmpC $\beta$-lactamases are of major clinical concern as they are usually resistant to all the $\beta$-lactam drugs, except for cefepime, cefpirome, and carbapenems [12].

In the present study, AmpC genes responsible for cephalosporinases were observed in two Shigella isolates, one with CIT and FOX genes and the other with $C I T$ gene only that were phenotypically resistant to cefotaxime and cefixime. In contrast, all four MDR STM were found to be negative for AmpC genes. In addition, the $b l a_{\text {СтХ-м-1 }}$ gene was found in three Shigella isolates and three STM by conferring resistance to third-generation cephalosporins. Two other Shigella isolates neither possessed AmpC nor bla $a_{\text {CTX-M-1 }}$ genes but were phenotypically resistant to cephalosporins. The resistance mechanism is not known. The co-existence of CIT-FOX genes was previously reported in other Enterobacteriaceae isolates [13]. However, the current study is the first report of CIT-FOX occurrence in Shigella spp. among Indian isolates.

Further, all six $b l a_{\text {CTX-M-1 }}$ amplicons were sequenced (3130 Genetic Analyzer, Applied Biosystems, Waltham, USA) and identified to be the bla $a_{\text {СтХ-M-15 }}$ subtype with GC content $50.4 \%$. The accession numbers for the sequences submitted to NCBI are SH1 - KP851743, SH2 - KP851744, SH3 KP851748, S1 - KP851745, S2 - KP851746, S3 KP851747. The amplicons sequences were $100 \%$ identical to the NCBI GenBank sequence (KJ406378.1).

The association of bla $a_{\text {CTX-M-15 }}$ with $q n r$ and other ESBLs had been previously reported in various countries such as Denmark [14], Netherlands [15], Spain [16], and Germany [17]. However, such findings are not reported among the Indian isolates. To the best of our knowledge, this is the first Indian study to report the association of $b l a_{\mathrm{CTX}-\mathrm{M}-15}$ with PMQR genes, i.e., qnrS and $q n r B$ among the Shigella spp and NTS respectively.

bla $a_{\mathrm{CTX}-\mathrm{M}-15}$ and $q n r \mathrm{~B}$ in STM were also associated with ESBL (bla $a_{\text {OXA }}$ and $\left.b l a_{\text {TEM }}\right)$ and sul2 genes. Similar observations were documented by Geetha et al. [18]. In contrast, bla $a_{\mathrm{CTX}-\mathrm{M}-15}$ and $q n r S$ were associated with dhfrla and sul2 genes in MDR Shigella spp.

Thus, close linkage between different resistance determinants may lead to high prevalence of multi drug resistance strains under antibiotic-specific selective pressure, which in turn may limit the use of valuable antibiotics in managing non-typhoidal Salmonella and Shigella infections.

\section{Conclusion}

In the present study, the acquisition of MDR is genotypically proven by the strong association of ESBL genes (bla $\left.a_{\mathrm{OXA}}, \quad b l a_{\mathrm{TEM}}, \quad b l a_{\mathrm{CTX}-\mathrm{M}-15}\right)$ with sulfamethoxazole resistance and PMQR genes. This multiple resistance mechanism poses a major threat for the dissemination. Especially, the co-existence of the resistance determinants on transferable plasmids may lead to the emergence and spread of MDR pathogens rapidly in various species within the country. This implies that an intense surveillance is needed to identify the trend and implement judicious use of antibiotics to minimize the selective pressure on bacteria.

\section{Acknowledgements}

The authors gratefully acknowledge the Indian Council of Medical Research, New Delhi for providing the grant for 
this research (Ref. No: AMR/TF/55/13ECDII dated 23/10/2013) and the Institutional Review Board of the Christian Medical College, Vellore (83-i/11/13).

\section{References}

1. Zaidi MB, Estrada-García T, Campos FD, Chim R, Arjona F, Leon M, Michell A, Chaussabel D (2013) Incidence, clinical presentation, and antimicrobial resistance trends in Salmonella and Shigella infections from children in Yucatan, Mexico. Front Microbiol 4: 288.

2. Nath R, Saikia L, Choudhury G, Sharma D (2013) Drug resistant Shigella flexneri in \& around Dibrugarh, north-east India. Indian J Med Res 137: 183-186.

3. Ashtiani MTH, Monajemzadeh M, Kashi L (2009) Trends in antimicrobial resistance of fecal shigella and Salmonella isolates in Tehran, Iran. Indian J pathol microbiol 52: 52-55.

4. Singh S, Agarwal RK, Tiwari SC, Singh H (2012) Antibiotic resistance pattern among the Salmonella isolated from human, animal and meat in India. Trop Anim Health Prod 44: 665674.

5. Taneja N, Appannanavar SB, Kumar A, Varma G, Kumar Y, Mohan B, Sharma M (2014) Serotype profile and molecular characterization of antimicrobial resistance in non-typhoidal Salmonella isolated from gastroenteritis cases over nine years. J Med Microbiol 63: 66-73.

6. CLSI (2014) Performance Standards for Antimicrobial Susceptibility Testing; Twenty-Fourth Informational Supplement M100-S24.

7. Pfeifer Y, Matten J, Rabsch W (2009) Salmonella enterica serovar Typhi with CTX-M beta-lactamase, Germany. Emerg Infect Dis 15: 1533-1535.

8. Chang CY, Lu PL, Lin CC, Lee TM, Tsai MY, Chang LL (2010) Integron types, gene cassettes, antimicrobial resistance genes and plasmids of Shigella sonnei isolates from outbreaks and sporadic cases in Taiwan. J Med Microbiol 60: 197-204.

9. Liu Y, Yachao LH Pan, Cheng J, Zhu Y, Ye Y, Li J (2012) Prevalence of plasmid-mediated quinolone resistance determinants in association with b-lactamases, 16S rRNA methylase genes and integrons amongst clinical isolates of Shigella flexneri. J Med Microbiol 61: 1174-1176.

10. Folster JP, Pecic G, Krueger A, Rickert R, Burger K, Carattoli A, Whichard JM (2010) Identification and Characterization of CTX-M-Producing Shigella Isolates in the United States. Antimicrob Agents Chemother 54: 2269-2270.

11. Menezes GA, Khan MA, Harish BN, Parija SC, Goessens W, Vidyalakshmi K, Baliga S, Hays JP (2010) Molecular characterization of antimicrobial resistance in non-typhoidal salmonellae associated with systemic manifestations from India. J Med Microbiol 59: 1477-1483.
12. Perez-Perez FJ, Hanson ND (2002) Detection of PlasmidMediated AmpC -Lactamase Genes in Clinical Isolates by Using Multiplex PCR. J Clin Microbiol 40: 2153-2162.

13. Manoharan A, Sugumar M, Kumar A, Jose H, Mathai D (2012) Phenotypic \& molecular characterization of AmpC $\beta$ lactamases among Escherichia coli, Klebsiella spp. \& Enterobacter spp. from five Indian Medical Centers. Indian J Med Res 135: 359-364.

14. Dolejska M, Villa L, Hasman H, Hansen L, Carattoli A (2013) Characterization of IncN plasmids carrying bla CTX-M-I $_{1}$ and $q n r$ genes in Escherichia coli and Salmonella from animals, the environment and humans. J Antimicrob Chemother 68: 333-339.

15. Veldman K, Dierikx C, Zandbergen AVE, Pelt WV, Mevius D (2010) Characterization of multidrug-resistant, qnrB2positive and extended-spectrum-b-lactamase-producing Salmonella Concord and Salmonella Senftenberg isolates. J Antimicrob Chemother 65: 872-875.

16. Gonzalez-Lopez JJ, Carrasco NP, Salvador F, Rodriguez V, Montalva AS, Planes AM, Molina I, Larrosa MN (2014) ESBL-Producing Salmonella enterica Serovar Typhi in Traveler Returning from Guatemala to Spain. Emerg Infect Dis 20: 1918-1920.

17. Schmiedel J, Falgenhauer L, Domann E, Bauerfeind R, Berninghoff EP, Imirzalioglu C, Chakraborty T (2014) Multiresistant extended-spectrum $\beta$-lactamase producing Enterobacteriaceae from humans, companion animals and horses in central Hesse, Germany. BMC Microbiol 14: 187.

18. Geetha VK, Yugendran T, Srinivasan R, Harish BN (2014) Plasmid-mediated quinolone resistance in typhoidal Salmonellae: A preliminary report from South India. Ind J Med Microbiol 32: 31-34.

19. Ghosh S, Pazhanil GP, Niyogil SK, James P. Nataro, Ramamurthy T (2014) Genetic Characterization of Shigella species Isolated from Diarrhoeal and Asymptomatic Children. J Med Microbiol 63: 903-910.

20. Taneja N, Mewara A, Kumar A, Verma G, Sharma JM (2012) Cephalosporin-resistant Shigella flexneri over 9 years (200109) in India. Antimicrob Chemother 67: 1347-1353.

\section{Corresponding author}

Dr. Balaji Veeraraghavan

Professor and Head

Department of Clinical Microbiology

Christian Medical College

Vellore - 632004

Tamil Nadu, India

Phone: +91-416-2282588

Email: vbalaji@cmcvellore.ac.in

Conflict of interests: No conflict of interests is declared. 